\title{
PERBEDAAN PENGARUH ANTARA EKSTRAK DAN REBUSAN DAUN SALAM (Eugenia polyantha) DALAM PENCEGAHAN PENURUNAN KADAR KOLESTEROL HDL PADA TIKUS SPRAGUE DAWLEY
}

\author{
Setya Fitriarini, Hesti Murwani $\mathbf{R}^{*)}$ \\ Program Studi Ilmu Gizi Fakultas Kedokteran Universitas Diponegoro \\ J1.Dr.Sutomo No.18, Semarang, Telp (024) 8453708, Email : gizifk@ undip.ac.id
}

\begin{abstract}
Backgorund: Coronary heart dissease (CHD) was the leading causes of death in the world. Decreased HDL cholesterol level is one of risk factor of CHD. Food intake management was effective to prevent decreased HDL level. Bay leaf contains flavonoid that was effective to increase HDL cholesterol level. The study aims to confirm the differences of HDL cholesterol decreased preventive properties between bay leaf extract and boiled in Sprague Dawley rats.

Methods: A true experimental study with pre-post test randomized control group design towards 24 Sprague Dawley rats which were divided into 4 groups. Negative control group was given standard diet and high fat diet, positive control group was given standard diet, high fat diet and simvastatin, and two treatment groups were given standard diet, high fat diet also extract made from 0,72 gram bay leaf and 0,72 gram boiled bay leaf for 14 days. HDL cholesterol level checked with Precipitation Of LDL,VLDL and Chylomicrons methods. Data were analysed by Paired t-test, Annova and LSD test with $95 \%$ CI.

Results :HDL cholesterol level was decreased significantly in all groups except in positive control group $(p=0,331)$. There was difference in delta HDL cholesterol level between all of groups $(p=0,000)$ except between in negative control group and boiled group. Decreased HDL cholesterol level in negative control group was 69,21\%, in positive control group was 6,08\%, in extract group was 34,64\%, and in boiled group was $60,87 \%$.

Conclusion: treatment that gave the best inhibitory effect in the rate of decreased HDL cholesterol level were 0,018 gram simvastatin (positive control group), 0,034 gram bay leaf extract and the last boiled bay leaf made from 0,72 gram fresh bay leaf.
\end{abstract}

Key Word: Extract; boiled; bay leaf; HDL Cholesterol content; Sprague dawley rats; flavonoid

\begin{abstract}
ABSTRAK
Pendahuluan : Hiperlipidemia merupakan salah satu faktor risiko penyakit jantung koroner (PJK) dikarenakan adanya kolesterol tinggi yang memicu terjadinya ateroskerosis. High Density Lipoprotein (HDL) menjadi salah satu faktor protektif terjadinya arterosklerosis. Daun salam mempunyai kandungan flavonoid yang dapat berfungsi sebagai antioksidan dan dapat menghambat penurunan kadar HDL. Tujuan penelitian adalah menganalisis perbedaan pengaruh antara pemberian ekstrak dan rebusan daun salam dalam pencegahan penurunan kadar kolesterol HDL pada tikus yang diberi pakan tinggi lemak.

Metode Penelitian : Sebuah penelitian eksperimental, dengan desain pre-post test randomized control group design. Subjek penelitian adalah 24 tikus putih Sprague dawley yang terbagi menjadi : kelompok kontrol positif, kontrol negatif, kelompok ekstrak dan rebusan yang terbuat dari 0,72 gram daun salam. Intervensi diberikan selama 14 hari. Pengukuran kadar kolesterol HDL dilakukan dengan menggunakan metode Precipitation Of LDL,VLDL and Chylomicrons. Uji normalitas menggunakan Shapiro Wilks, uji perbedaan kadar HDL awal dan akhir perlakuan dengan menggunakan paired t-test. Perbedaan pengaruh dari setiap kelompok perlakuan dianalisis dengan menggunakan uji Oneway ANOVA dilnjutkan dengan uji post-hock LSD.

Hasil Penelitian : Tiga kelompok perlakuan mengalami penurunan kadar kolesterol HDL yang bermakna $(p<0,05)$ dan untuk kelompok kontrol positif kadar kolesterol HDL pada awal-akhir penelitian tidak mengalami perubahan yang signifikan (p>0,05). Kelompok kontrol negatif mengalami penurunan kadar kolesterol HDL sebanyak 69,21\%, kontrol positif 6,08\%, kelompok ekstrak 34,64\% dan kelompok rebusan 60,87\%.

Kesimpulan : Kelompok perlakuan yang memberikan efek menghambatan laju penurunan kadar kolesterol HDL terbaik yaitu : simvastatin dengan dosis 0,018 gram, 0,034 gram ekstrak daun salam dan rebusan daun salam yang terbuat dari 0,72 gram daun salam segar.
\end{abstract}

Kata kunci : ekstak; rebusan; daun salam; kadar kolesterol HDL; tikus putih Sprague dawley ; flavonoid

\section{PENDAHULUAN}

Masalah kesehatan yang meningkat secara cepat di beberapa negara berkembang adalah penyakit tidak menular (non communicable disease). Penanganan penyakit tidak menular beda halnya dengan penyakit menular yang sudah 
diketahui dengan pasti penyebabnya. Faktor-faktor resiko yang saling bersinergis menyebabkan potensi dari penyakit tidak menular ini semakin meningkat. Salah satu penyakit tidak menular yang menyebabkan kematian tertinggi adalah penyakit jantung koroner (PJK). Badan kesehatan dunia (WHO) mencatat kematian akibat PJK berkisar antara 7 juta jiwa di seluruh dunia pada tahun 2002, dan diperkirakan akan meningkat menjadi 11 juta jiwa pada tahun 2020. Berdasarkan data Riset Kesehatan Dasar (RISKESDAS) 2007, prevalensi penyakit jantung di Indonesia adalah 7,2\%. Faktorfaktor risiko dari PJK antara lain hipertensi, merokok, diabetes, obesitas, asupan, hiperlipidemia. ${ }^{1,2,3}$

Hiperlipidemia menjadi salah satu faktor risiko PJK dikarenakan adanya kolesterol tinggi memicu terjadinya aterosklerosis, yang dapat menghambat aliran darah jantung. High Density Lipoprotein (HDL) merupakan suatu lipoprotein baik yang berfungsi mengangkut kembali sisa metabolisme kolesterol dalam jaringan dan mengembalikannya ke hati. HDL menjadi salah satu faktor protektif terjadinya arterosklerosis. ${ }^{4,5}$

Banyak cara yang dapat digunakan sebagai upaya pencegahan penurunan kolesterol HDL selain dengan menggunakan obat. Penggunaan obat tradisional dapat dijadikan sebagai salah satu alternatif upaya preventif. $^{2}$ Beberapa penelitian tentang sejumlah bahan alam membuktikan bahwa kekayaan alam dapat dimanfaatkan sebagai obat. Tanaman yang sudah diteliti dapat meningkatkan kadar HDL adalah daun salam. Penelitian yang dilakukan pada tahun 2008 menunjukan bahwa pemberian ekstrak yang berasal dari 0,72 gr daun salam segar dapat meningkatkan kadar HDL secara signifikan pada tikus hiperlipidemia. ${ }^{6}$

Upaya pencegahan lebih penting daripada pengobatan, pernyataan ini yang membuat peneliti tertarik untuk meneliti pengaruh dari daun salam dalam mempertahankan kadar kolesterol HDL. Mempertimbangkan sisi aplikatif dalam masyarakat maka peneliti juga ingin meneliti pengaruh dari rebusan daun salam. Perbedaan penelitian ini dengan penelitian sebelumnya adalah proses ekstraksi dengan menggunakan metode maserasi dan pelarut etanol, adanya intervensi rebusan daun salam segar dan tikus yang tidak dikondisikan hiperlipidemia pada awal. Jadi dalam penelitian ini menggambarkan perbedaan pengaruh dari ekstrak dan rebusan daun salam dalam mempertahankan kadar kolesterol HDL, dengan dibarengi pemberian pakan tinggi lemak.

\section{METODE PENELITIAN}

Penelitian ini termasuk dalam penelitian eksperimental, dengan desain pre-post test randomized control group design. Ruang lingkup keilmuan pada penelitian ini adalah gizi klinik. Penelitian ini dilaksanakan di Laboratorium Pusat Studi Pangan dan Gizi PAU Universitas Gadjah Mada. Variabel bebas dalam penelitian ini adalah pemberian ekstrak daun salam dan rebusan daun salam. Variabel tergantungnya adalah hasil pemeriksaan kadar kolesterol HDL hewan coba sedangkan variabel terkontrolnya adalah hewan coba, umur hewan coba, jenis kelamin hewan coba, pakan hewan coba, kandang dan sistem perkandangan hewan coba. Populasi target dalam penelitian ini adalah semua tikus putih jantan galur Sprague Dawley sebanyak 24 ekor tikus yang dibagi menjadi 4 kelompok perlakuan.

Kriteria tikus yang digunakan untuk penelitian ini yaitu umur $7-8$ minggu dan berat antara 180-200 gram. Kriteria inklusinya adalah tikus bergerak aktif, kondisi sehat dan secara makroskopik tidak terdapat kelainan serta bisa menerima perlakuan sesuai dengan prosedur penelitian yang dilakukan. Kriteria eksklusinya adalah tikus mengalami penurunan berat badan sebesar $10 \%$, sakit dan tidak bisa menerima perlakuan sesuai dengan prosedur penelitian yang akan dilakukan serta tikus mati saat berlangsungnya penelitian

Masing- masing kelompok terdiri dari 6 ekor tikus yang dirawat dalam kandang individu, setelah itu dilakukan pemeriksaan awal kadar kolesterol HDL yang akan digunakan sebagai data standar. Pengukuran kadar kolesterol HDL dalam serum dilakukan dengan menggunakan metode Precipitation Of LDL,VLDL and Chylomicrons. Sebelum dilakukan pemeriksaan, hewan coba dipuasakan selama 12 jam, setelah itu sampel darah diambil sebanyak $2 \mathrm{ml}$ melalui sinus orbitalis.

Kelompok kontrol (-) diberikan pakan standar, diet tinggi lemak dan air minum ad libitium; kelompok kontrol (+) diberikan pakan standar, diet tinggi lemak dan obat penurun kolesterol simvastatin; kelompok perlakuan 1 (ekstrak) diberi pakan standar, diet tinggi lemak, dan ekstrak daun salam; dan kelompok perlakuan 2 (rebusan) diberi pakan standar, diet tinggi lemak, dan rebusan daun salam. Pemberian ekstrak daun salam, rebusan daun salam dan simvastatin dilakukan sekali sehari. Pemberian diet tinggi lemak bertujuan untuk mempengaruhi kadar kolesterol HDL, sedang pemberian ekstrak dan 
rebusan daun salam diharapkan mampu mempertahankan kadar kolesterol HDL agar tidak mengalami penurunan. Perlakuan tersebut diberikan secara sonde selama 14 hari, setelah itu dipuasakan selama 12 jam dan diperiksa kadar kolesterol HDL akhir. Dosis simvastatin sebanyak $0,018 \mathrm{mg}$, pemberian ekstrak adalah 0,034 gram dan rebusan sebanyak 2,7 ml. Ekstrak dan rebusan terbuat dari 0,72 gram daun salam segar. Proses pembuatan ekstrak menggunakan metode maserasi, dengan etanol sebagai pelarutnya. Pemantauan berat badan, sisa pakan dan ada tidaknya diare pada subjek penelitian dilakukan setiap hari.

Data yang diperoleh diolah menggunakan program komputer. Data diuji kenormalan sebarannya dengan menggunakan Sapiho-Wilk, uji perbedaan kadar kolesterol HDL awal dan akhir perlakuan dengan menggunakan paired t-test, sedang perbedaan pengaruh dari setiap kelompok perlakuan dianalisis dengan menggunakan uji Oneway ANOVA. Perbedaan perubahan asupan pakan, asupan lemak dan berat badan menggunakan uji Kruskal Wallis karena data tidak berdistribusi normal. Uji lanjut untuk mengetahui kelompok yang berbeda menggunakan post-hoc test. $^{7}$

\section{HASIL PENELITIAN \\ Analisa Kandungan Flavonoid}

Uji laboratorium perlu dilakukan guna mengetahui berapa banyak kandungan total flavonoid dalam sampel ekstrak dan rebusan daun salam. Adapun hasil analisa kandungan total flavonoid dapat dilihat pada tabel 1.

Tabel 1. Hasil Analisa Kandungan Total Flavonoid

\begin{tabular}{cccc}
\hline & \multicolumn{3}{c}{ total flavonoid $(\mathrm{ppm})$} \\
\cline { 2 - 4 } & $\mathrm{I}$ & $\mathrm{II}$ & rata-rata \\
\hline ekstrak & $11.167,93$ & $11.194,09$ & $11.181,01$ \\
rebusan & 24,82 & 24,15 & 24,485 \\
\hline
\end{tabular}

Kadar total flavonoid pada ekstrak jauh lebih besar jika dibandingkan dengan kandungan total flavonoid dalam rebusan.

\section{Karateristik Sampel}

Dua puluh empat tikus jantan Sprague Dawley dipelihara dalam kandang individual. Selama perlakuan berlangsung tidak ada seekor tikus pun yang mati. Semua tikus sehat sehingga dapat digunakan sebagai sebjek penelitian hingga penelitian usai.

Diare merupakan kondisi dimana konsistensi kotoran (tinja) dan frekuensi buang air besar lebih sering dari keadaan normal. Diare merupakan indikator yang paling sederhana untuk mengamati ada tidaknya gangguan malabsorbsi lemak yang terjadi. Selama penelitian berlangsung tidak ditemukan tikus yang mengalami diare. Ini dapat diartikan bahwa pemberian ekstrak dan rebusan daun salam tidak menimbulkan efek diare pada tikus. ${ }^{8}$

Data dari tabel 2 di bawah ini merupakan gambaran umum perubahan asupan pakan, asupan lemak, berat badan dan kadar kolesterol HDL untuk semua kelompok perlakuan.

Tabel 2 Hasil Analisa Uji Beda $\Delta$ Asupan, $\Delta \%$ Asupan Lemak, $\Delta$ Berat Badan, dan $\Delta$ HDL Antar Kelompok Perlakuan

\begin{tabular}{ccccc}
\hline \multirow{2}{*}{ Kelompok } & $\begin{array}{c}\Delta \text { Asupan } \\
(\mathrm{gr})\end{array}$ & $\begin{array}{c}\Delta \% \text { Asupan Lemak } \\
(\%)\end{array}$ & $\begin{array}{c}\Delta \text { Berat Badan } \\
(\mathrm{gr})\end{array}$ & $\begin{array}{c}\Delta \text { HDL } \\
(\mathrm{mg} / \mathrm{dl})\end{array}$ \\
\hline Kontrol $(-)$ & $1,17 \pm 1,17$ & $35,23 \pm 0,72$ & $14 \pm 1,09$ & $35,59 \pm 0,88$ \\
Kontrol (+) & $1,0 \pm 0,63$ & $35,58 \pm 0,33$ & $15,17 \pm 0,98$ & $2,8 \pm 0,33$ \\
Ekstrak & $1,0 \pm 0,63$ & $35,06 \pm 0,33$ & $14,5 \pm 0,55$ & $15,42 \pm 0,81$ \\
Rebusan & $0,83 \pm 0,41$ & $35,49 \pm 0,39$ & $16,5 \pm 1,22$ & $32,44 \pm 0,53$ \\
$p$ & $0,961^{\mathrm{a} *}$ & $0,961^{\mathrm{a} *}$ & $0,017^{\mathrm{a} *}$ & $0,000^{\mathrm{b} *}$ \\
\hline
\end{tabular}

* memiliki perbedaan yang bermakna $(\mathrm{p}<0,05)$

a Uji Kruskal Wallis. Uji lanjut Post-hoc Mann-Whitney untuk $\Delta$ Berat Badan : $\mathrm{k}(+)$ vs $\mathrm{k}(-) \mathrm{p}=0,092$; $\mathrm{k}(+)$ vs ekstrak $\mathrm{p}=0,201 ; \mathrm{k}(+)$ vs rebusan $\mathrm{p}=0,028 ; \mathrm{k}(-)$ vs ekstrak $\mathrm{p}=0,423 ; \mathrm{k}(-)$ vs rebusan $\mathrm{p}=0,014$; ekstrak vs rebusan $\mathrm{p}=0,021$

b Uji One Way Anova 
Data dari tabel 2 di atas menunjukkan bahwa untuk asupan pakan dan asupan lemak pada semua kelompok perlakuan tidak memiliki perbedaan. Sedangkan untuk berat badan dan kadar kolesterol HDL antar kelompok memiliki perbedaan yang signifikan $(\mathrm{p}<0,05)$. Kelompok yang mempunyai perbedaan berat badan adalah kelompok kontrol (+) vs kelompok rebusan, kelompok $\mathrm{k}(-)$ vs kelompok rebusan dan kelompok ekstrak vs kelompok rebusan.

Pemantauan berat badan dilakukan untuk melihat seberapa besar penambahan berat badan tikus selama proses penelitian berlangsung, karena dalam penelitian ini berat badan juga merupakan variabel terkontrol. Tabel 3 di bawah ini memperlihatkan perubahan tikus selama penelitian berlangsung.

Tabel 3. Berat Badan Subjek pada Awal dan Akhir Perlakuan

\begin{tabular}{|c|c|c|c|c|}
\hline \multirow[t]{2}{*}{ Kelompok } & \multicolumn{2}{|c|}{ Berat Badan Subjek } & \multirow[t]{2}{*}{$\Delta$} & \multirow[t]{2}{*}{$p$} \\
\hline & Awal (gr) & Akhir (gr) & & \\
\hline Kontrol (-) & $191,83 \pm 9,28$ & $205,83 \pm 9,41$ & $14 \pm 1,09$ & $0,000^{*}$ \\
\hline Kontrol (+) & $188,17 \pm 6,34$ & $203,33 \pm 5,85$ & $\begin{array}{c}15,17 \pm \\
0,98\end{array}$ & $0,000^{*}$ \\
\hline Ekstrak & $189,5 \pm 7,84$ & $204 \pm 7,46$ & $14,5 \pm 0,55$ & $0,000 *$ \\
\hline
\end{tabular}

*memiliki perbedaan yang bermakna $(\mathrm{p}<0,05)$

Tabel 3 menunjukkan bahwa dari keempat kelompok mempunyai perbedaan berat awal dan berat akhir yang bermakna $(p<0,05)$. Kelompok yang mempunyai perubahan berat badan yang paling signifikan adalah kelompok rebusan, sedangkan kelompok yang mengalami kenaikan berat badan yang paling rendah adalah kelompok kontrol (-).

Pemantauan asupan dilakukan dari hasil penimbangan sisa pakan per harinya. Rerata asupan makan pada awal dan akhir penelitian dapat dilihat dari tabel 4 di bawah ini.

Tabel 4. Asupan Pakan Subjek pada Awal dan Akhir Perlakuan

\begin{tabular}{ccccc}
\hline \multirow{2}{*}{ Kelompok } & \multicolumn{2}{c}{ Asupan Pakan Subjek } & $\Delta$ & $\boldsymbol{p}$ \\
\cline { 2 - 3 } & Awal (gr) & Akhir (gr) & & \\
\cline { 1 - 3 } Kontrol (-) & $16,17 \pm 0,75$ & $17,33 \pm 1,37$ & $1,17 \pm$ & $0,022^{*}$ \\
Kontrol (+) & $17,0 \pm 0,89$ & $18,0 \pm 0,6$ & $1,0 \pm 0,63$ & $0,016^{*}$ \\
Ekstrak & $16,0 \pm 0,89$ & $17,0 \pm 0,63$ & $1,0 \pm 0,63$ & $0,012^{*}$ \\
Rebusan & $17,0 \pm 0,63$ & $17,83 \pm 0,75$ & $0,83 \pm$ & $0,004^{*}$ \\
\hline
\end{tabular}

*memiliki perbedaan yang bermakna $(\mathrm{p}<0,05)$

Berdasarkan data yang disajikan pada tabel 4 dapat dilihat bahwa keempat kelompok mempunyai perbedaan asupan pakan yang bermakna antara awal dan akhir penelitian (p $<0,05)$. Perubahan asupan awal dan akhir yang paling besar adalah pada kelompok kontrol (-), sedang pada kelompok kontrol (+) dan kelompok ekstrak mempunyai perbedaan asupan makan pada awal dan akhir penelitian yang paling rendah.

Asupan makan berpengaruh terhadap asupan lemak. Semakin banyak makanan yang diasup maka asupan lemak juga akan meningkat. Adapun prosentase asupan lemak subjek dapat dilihat dari tabel 5 di bawah ini.

Tabel 5. Prosentase Asupan Lemak Subjek pada Awal dan Akhir Perlakuan

\begin{tabular}{|c|c|c|c|c|}
\hline \multirow[t]{2}{*}{ Kelompok } & \multicolumn{2}{|c|}{ Asupan Lemak Subjek } & \multirow[t]{2}{*}{$\Delta$} & \multirow[t]{2}{*}{$p$} \\
\hline & Awal (\%) & Akhir (\%) & & \\
\hline Kontrol (-) & $34,62 \pm 0,39$ & $35,23 \pm 0,72$ & $\begin{array}{c}0,61 \pm \\
0,61\end{array}$ & 0,058 \\
\hline Kontrol (+) & $35,06 \pm 0,47$ & $35,58 \pm 0,33$ & $\begin{array}{c}0,52 \pm \\
0,33\end{array}$ & 0,012 \\
\hline
\end{tabular}




\begin{tabular}{ccccc}
\hline \multirow{2}{*}{ Ekstrak } & $34,54 \pm 0,47$ & $35,06 \pm 0,33$ & $0,52 \pm$ & 0,012 \\
& & & 0,33 & \\
Rebusan & $35,06 \pm 0,33$ & $35,49 \pm 0,39$ & $0,44 \pm$ & 0,004 \\
& & & 0,21 & \\
\hline
\end{tabular}

*memiliki perbedaan yang bermakna $(\mathrm{p}<0,05)$

Berdasarkan data dari tabel 5, rata-rata prosentase asupan lemak adalah diatas $34 \%$ dari total kebutuhan energi. Tingginya asupan lemak ini dikarenakan asupan lemak yang berasal dari pakan dan lemak babi yang diberikan langsung secara sonde. Pemberian lemak babi secara sonde membuat lemak terasup oleh subjek secara adekuat.

Pemeriksaan kadar kolesterol HDL dilakukan pada awal, tengah dan akhir dari penelitian. Tabel 6 berikut adalah gambaran dari hasil pemeriksaan kadar kolesterol HDL yang telah dilakukan.

Tabel 6. Kadar HDL Subjek pada Awal dan Akhir Penelitian

\begin{tabular}{ccccc}
\hline \multirow{2}{*}{ Kelompok } & \multicolumn{2}{c}{ Kadar HDL Subjek } & $\Delta$ & $\boldsymbol{p}$ \\
\cline { 2 - 3 } & Awal (gr/dl) & Akhir $(\mathbf{g r} / \mathbf{d l})$ & & \\
\hline Kontrol (-) & $51,42 \pm 2,89$ & $15,83 \pm 2,01$ & $35,59 \pm 0,88$ & $0,000^{*}$ \\
Kontrol (+) & $46,05 \pm 2,85$ & $43,25 \pm 2,52$ & $2,8 \pm 0,33$ & 0,331 \\
Ekstrak & $44,51 \pm 2,06$ & $29,09 \pm 1,25$ & $15,42 \pm 0,81$ & $0,000^{*}$ \\
Rebusan & $53,29 \pm 1,91$ & $20,85 \pm 2,44$ & $32,44 \pm 0,53$ & $0,000^{*}$ \\
\hline
\end{tabular}

*memiliki perbedaan yang bermakna $(\mathrm{p}<0,05)$

Data dari tabel 6 di atas menunjukkan bahwa terdapat tiga kelompok perlakuan yang mengalami penurunan kadar kolesterol HDL $(\mathrm{p}<0,05)$ dan untuk kelompok kontrol (+) kadar kolesterol HDL pada awal-akhir penelitian tidak mengalami perubahan dengan nilai $\mathrm{p}=0,331(\mathrm{p}>0,05)$.

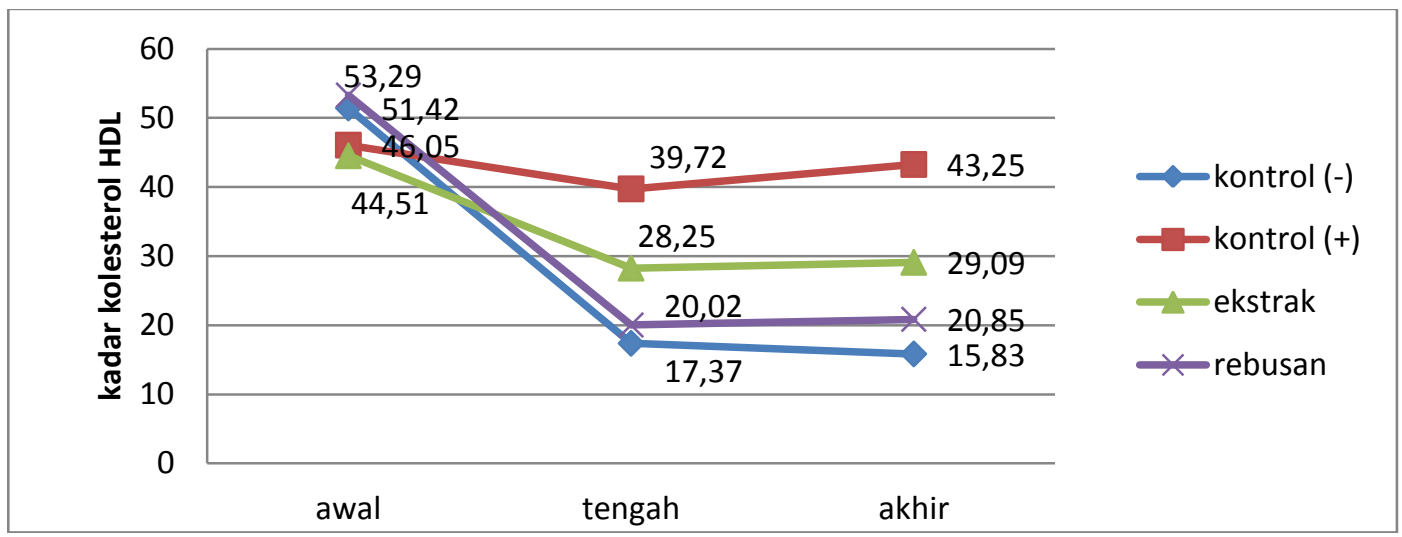

Gambar 1. Grafik Perubahan Kadar Kolesterol HDL

Gambar 1 menunjukkan grafik perubahan kadar kolesterol HDL pada awal, tengah dan akhir penelitian untuk masing-masing kelompok perlakuan. Grafik tersebut menunjukkan trend penurunan untuk setiap kelompok perlakuan. penurunan yang paling signifikan adalah pada kelompok kontrol (-). Kelompok kontrol (+) cenderung mempunyai kadar kolesterol yang lebih stabil jika dibandingkan dengan ketiga kelompok lainnya.

\section{PEMBAHASAN}

\section{Kandungan Total Flavonoid}

Hasil analisa total flavonoid pada sampel menunjukkan bahwa kandungan total flavonoid ekstrak jauh lebih tinggi jika dibandingkan dengan rebusan. Proses pemanasan sangat berpengaruh terhadap kandungan total flavonoid karena sifatnya yang sangat rentan terhadap panas. Proses ekstraksi dengan menggunakan metode maserasi menggunakan suhu $60-70{ }^{\circ} \mathrm{C}$ sedang perebusan suhunya mencapai $100{ }^{\circ} \mathrm{C}$. Namun jika dilihat dari dampak pemberian ekstrak dan rebusan terhadap kadar kolesterol HDL tidak mengalami perbedaan 
yang signifikan. Niasin dan magnesium yang terkandung dalam daun salam juga diketahui berperan dalam meningkatkan kadar kolesterol HDL.

\section{Berat Badan dan Asupan Pakan Subjek Penelitian}

Pakan standar diberikan sebanyak 20 gram/200 gram BB/hari dan diet tinggi lemak berupa lemak babi sebanyak $10 \%$ dari jumlah pakan standar. Kebutuahan energi tikus rata-rata adalah 68,8 kalori. Hasil uji statistik menunjukkan adanya perbedaan asupan makan awal - akhir yang signifikan pada semua kelompok perlakuan, sedangkan jika dilihat dari delta perubahan asupan makan tidak terdapat perbedaan yang bermakna antar kelompok perlakuan.

Prosentase lemak untuk diet tinggi lemak adalah sebanyak $25-40 \%$ dari total energi. Rerata asupan lemak dari seluruh subjek adalah diatas $34 \%$. Lemak babi ini diberikan secara sonde sehingga dapat dipastikan lemak terasup lebih sempurna oleh subjek jika dibandingkan dengan pencampuran lemak babi pada pakan tikus. Lemak mengandung $9 \mathrm{kalori} /$ gram, sehingga semakin banyak lemak yang terasup maka semakin banyak energinya. Kecukupan energi dapat mempengaruhi perubahan berat badan. Asupan makan dan asupan lemak yang tinggi ini dapat menjadi salah satu faktor penyebab adanya peningkatan berat badan subjek. Selain itu faktor aktifitas dari subjek itu sendiri, dimana subjek ditempatkan dalam kandang individu yang secara tidak langsung membatasi aktifitas fisiknyanya sehingga tidak bisa bebas jika dibandingkan dengan tikus yang hidup di luar kandang yang sangat bebas. ${ }^{9,10}$

\section{Pengaruh Pemberian Ekstrak Daun Salam dan Rebusan Daun Salam Dalam Peningkatan Kadar HDL}

Hasil analisis menunjukkan adanya penurunan yang signifikan antara kadar HDL awal dan akhir yang bermakna pada setiap kelompok perlakuan $(\mathrm{p}<0,05)$ kecuali kelompok kontrol $(+)$. Kelompok kontrol (+) mengalami penurunan kadar kolesterol HDL awal dan akhir namun tidak signifikan $(\mathrm{p}=0,331)$, hal ini terlihat dari nilai delta kolesterol HDL awal - akhir yang relatif kecil. Sedangkan pada kelompok kontrol (-), kelompok ekstrak dan kelompok rebusan mengalami penurunan kadar HDL yang cukup banyak.

Hasil penelitian ini dapat menunjukkan bahwa dengan konsumsi lemak yang tinggi, terutama lemak jenuh dapat menurunkan kadar HDL. Penurunan kadar kolesterol HDL pada minggu pertama penelitian setelah dihitung ratarata mencapai $66 \%$ untuk kelompok kontrol (-), $13,44 \%$ pada kelompok kontrol (+), 36,47\% untuk kelompok ekstrak dan 62,43\% untuk kelompok ekstrak. Lemak babi sendiri memiliki kandungan lemak jenuh sebanyak $21 \%$. Lemak babi dalam penelitian ini terasup $100 \%$ sehingga sumbangan lemak jenuh yang terkandung didalamnya juga berimbas terhadap penurunan kadar kolesterol HDL. Meski pemberian ekstrak dan rebusan tidak mampu mempertahankan kadar kolesterol HDL, tetapi kedua cara tersebut terbukti mampu memperlambat laju penurunan kadar kolesterol HDL agar tidak turun drastis seperti pada kelompok kontrol (-) yang tidak diberikan perlakuan apapun. Perlakuan yang paling efektif untuk mencegah penurunan kadar HDL dilihat dari delta HDL awal dan akhir adalah : pertama kelompok kontrol (+), kedua kelompok ekstrak daun salam, dan ketiga adalah kelompok rebusan daun salam. ${ }^{11,12}$

Ekstrak daun salam dan rebusan daun salam terbukti dapat mencegah laju penurunan kadar kolesterol HDL meski tidak sebanding dengan simvastatin, yang merupakan obat terstandar. Hal ini disebabkan adanya kandungan flavonoid yang dikandung oleh daun salam. Hasil analisa menunjukkan bahwa kandungan total flavonoid dalam ekstrak relatif banyak jika dibandingkan dengan rebusan. Kandungan total flavonoid dalam rebusan banyak hilang saat terjadi pemanasan sedangkan proses ekstraksi sendiri tidak menggunakan panas yang terlalu tinggi dan menggunakan pelarut khusus sehingga kandungan total flavonoid dalam ekstrak lebih banyak. Meskipun kandungan total flavonoid jauh berbeda, akan tetapi efek pencegahan laju penurunan kadar kolesterol HDL antara ekstrak dan rebusan daun salam tidak jauh berbeda. Hal ini disebabkan karena selain flavonoid daun salam juga mengandung niasin dan magnesium,yang berperan dalam meningkatkan kadar kolesterol HDL. Niasin dan magnesium bersifat tahan panas, sehingga tidak mudah rusak saat terjadi pemanasan. Sebuah penelitian menunjukkan bahwa peningkatan kadar trigliserida dan penurunan kadar kolesterol apabila terjadi defisiensi magnesium. ${ }^{13,14}$

Flavonoid selain berfungsi sebagai antioksidan juga dapat meningkatkan produksi apo AI. Jumlah apo AI yang meningkat dapat memberikan efek peningkatan kolesterol HDL dan kolesterol LDL menjadi tidak rentan terhadap reaksi oksidasi. Flavonoid dapat menghambat pengeluaran atau sekresi apo B100 ke intestinum, 
akibatnya jumlah apo-B akan menurun. Apo B merupakan pembentuk VLDL dan LDL. Kadar kolesterol HDL mengalami peningkatan secara tidak tangsung yang disebabkan karena penurunan kadar VLDL, LDL dan trigliserida serta meningkatnya produksi apo AI dan apo AII. ${ }^{15,16,17}$

Penelitian sebelumnya menunjukkan bahwa ekstrak yang terbuat dari 0,72 gram daun salam segar mampu meningkatkan kadar kolesterol HDL pada tikus yang mengalami dislipidemia, dengan dibarengi konsumsi lemak antara 7-10\% dari total energi. Beda dengan penelitian ini adalah prosentase asupan lemak antara 34,54 - 35,58\% dari tolal energi. ${ }^{6}$ Sehingga dapat ditarik kesimpulan sementara bahwa ekstrak dari 0,72 gram daun salam yang digunakan dalam penelitian yang bersifat preventif, serta diimbangi dengan asupan pakan tinggi lemak ini kurang bekerja secara optimal. Namun dapat dilihat bahwa ekstrak daun salam dan rebusan daun salam dapat menghambat laju penurunan kadar kolesterol HDL jika dibandingkan dengan kelompok kontrol negatif. Selain itu jumlah asupan dan jenis lemak yang dikonsumsi juga berpengaruh terhadap kadar kolesterol HDL. Ekstrak dan rebusan daun salam dapat berpotensi untuk mempertahankan kadar kolesterol HDL jika dosis yang digunakan tepat serta diimbangi dengan pengaturan pola makan terutama asupan lemak yang baik.

\section{SIMPULAN}

Kelompok perlakuan yang memberikan efek menghambatan laju penurunan kadar kolesterol HDL terbaik yaitu : simvastatin dengan dosis 0,018 gram, 0,034 gram ekstrak daun salam dan rebusan daun salam yang terbuat dari 0,72 gram daun salam segar.

\section{SARAN}

Ekstrak dan rebusan daun salam dapat dimanfaatkan untuk meningkatkan kadar kolesterol $\mathrm{HDL}$, disamping dengan tetap mengkonsumsi obat.

\section{DAFTAR PUSTAKA}

1. Ismantri F. Prevalensi Penderita Penyakit Jantung Koroner dengan Kadar Kolesterol-HDL Rendah Di RS. Binawaluya Tahun 2008-2009. Takultas Kedokteran dan Ilmu Kesehatan Universitas Islam Negeri Syarif Hidayatullah [serial online]. 2009. [dikutip pada tanggal 1 Juni 2013]. Diakses dari : http://perpus.fkik.uinjkt.ac.id/file digital/FABIYO \%20ISMANTRI.pdf

2. Artanti D. Pengaruh Pemberian Jus Buah Pare (Momordica Charantia) Terhadap Kadar Trigliserida Serum Tikus Wistar Jantan yang
Diberi Diet Tinggi Lemak. Fakultas Kedokteran Universitas Diponegoro. [serial online]. 2008. [dikutip pada tanggal 9 Juni 2013]. Diakses dari : http://eprints.undip.ac.id/23955/

3. Brown ML. Present Knowledge in Nutrition Sixth Edition. International Life Sciences Institute Nutrition Foundation. Whoshington DC ; 1990

4. Agung V. Pengaruh Pemberian Ekstrak Daun Salam (Eugenia Polyantha) Terhadap Kadar HDL Kolesterol Serum Tikus Jantan Galur Wistar Hiperlipidemia. Fakultas Kedokteran Universitas Diponegoro. [serial online]. 2008. [dikutip pada tanggal 21 Juni 2013]. Diakses dari : http://eprints.undip.ac.id/24184/1/Vincentius.pdf

5. Iswari RS, Manalu W. Biokimia dan Fisiologi Lipid. Karya Putra Darwanti

6. Agung V. Pengaruh Pemberian Ekstrak Daun Salam (Eugenia Polyantha) Terhadap Kadar HDL Kolesterol Serum Tikus Jantan Galur Wistar Hiperlipidemia. Fakultas Kedokteran Universitas Diponegoro. [serial online]. 2008. [dikutip pada tanggal 21 Juni 2013]. Diakses dari : http://eprints.undip.ac.id/24184/1/Vincentius.pdf

7. Dahlan S. Statistik untuk Kedokteran dan Kesehatan Edisi 5. Penerbit Salemba Medika. Jakarta ; 2011

8. Nuratmi B, Nugroho YA, Sundari B. Efek Antidiare Jus Temu Putih (Curcuma zedoaria Rosc.) dan Temu Mangga (Curcuma mangga Val. Et. Zipp.) pada Tikus Putih. Media Litbang Kesehatan Vol. XVI nomor 1 tahun 2006. [artikel online]. 2006 [dikutip pada tanggal 20 September 2013]. Diakses dari http://ejournal.litbang.depkes.go.id/index.php/MP K/article/ download/1120/513

9. Luthfiyah F, Widjajanto E. Jurnal Kedokteran Brawijaya, Vol. 26, No. 3, Februari 2011 : Serbuk Daun Kelor Memulihkan Kondisi Fisik Gizi Buruk pada Tikus Model Kurang Energi Protein. Fakultas Kedokteran Universitas Brawijaya.

10. Mahan LK, Stump SE, Rymon JL. Krause's Food and the Nutritions Care Proces Edition 13. USA ; 2012.

11. Tuminah S. Media Peneliti dan Pengembang Kesehatan. Volume XIX Tahun 2009, Suplemen II : Efek Asam Lemak Jenuh dan Asam Lemak Tak Jenuh "Trans" Terhadap Kesehatan. Puslitbang Biomedis dan Farmasi. [serial online]. 2009. [dikutip pada tanggal 28 Juni 2013]. Diakses dari : http://ejournal.litbang.depkes.go.id/index.php/MP K/article/download/751/1685

12. Hermanto S, Munawaroh A, Harahap R. Profil dan Karakteristik Lemak Hewani (Ayam, Sapi dan Babi) Hasil Analisa FTIR dan GCMS. Program Studi Kimia, Fakultas Sains dan Teknologi Universitas Islam Negeri Syarif Hidayatullah Jakarta. [serial online]. 2008. [dikutip tanggal 12 September 2013]. Diakses dari : 
http://journal.uinjkt.ac.id/index.php/valensi/article/ download/219/137

13. Mughni A. Pengaruh Puasa Ramadhan Terhadap Faktor-Faktor Risiko Aterosklerosis : Studi Pada Profil Lipid, Gula Darah, Tekanan Darah Dan Berat Badan. Program Pasca Sarjana Magister Ilmu Biomedik Dan Program Pendidikan Dokter Spesialis I Ilmu Bedah Universitas Diponegoro. [serial online]. 2007. [dikutip pada tanggal 28 Juni 2013]. Diakses dari eprints.undip.ac.id/16088/1/Abdul_Mughni.pdf

14. Bamba V, Rader DJ. Obesity and Atherogenic Dyslipidemia ; Gastroenterology 2007;132:21812190 . the Division of Endocrinology, Children's Hospital of Philadelphia; and the $\dagger$ Institute for Diabetes Obesity and Metabolism, Cardiovascular Institute, and Institute for Translational Medicine and Therapeutics, University of Pennsylvania School of Medicine. [serial online]. 2007. [dikutip pada tanggal 23 April 2013]. Diakses dari : http://www.gastrojournal.org/article/S00165085\%2807\%2900582-3/abstract

15. Mamad S. Faktor-Faktor yang Berhubungan dengan Kadar Kolesterol HDL (Analisis Data of The Indonesian Family Life Survey 2007/2008). Gizi Indon 2010, 33(2):143-149. Poltekkes Depkes Bandung dan Puslitbang Gizi dan Makanan Bogor. [serial online]. 2010. [dikutip pada tanggal 17 April 2013]. Diakses dari : http://www.persagi.org/document/makalah/181_m akalah.pdf

16. Laili N, Luqman EM, Lukismanto BS. The Effect of Black Soybean Milk on Liver to Recovery Histopathology in RAT (Rattus norvegicus) with High Fat Diet. Fakultas Kedokteran Hewan Universitas Airlangga. [serial online].[dikutip pada tanggal 11 April 2013]. Diakses dari : http://fkh.unair.ac.id/mahasiswa/Angkatan\%20200 5/ARTIKEL\%20ILMIAH\%20pdf\%20Noer\%20La ili\%281\%29.pdf

17. Robles NR, Escola JM, Albarran L, Espada R. Correlations of Serum Magnesium and Serum Lipid Levels in Hemodialysis Patients. [serial online]. [dikutip tanggal 12 April 2013]. Diakses dari : http://content.karger.com/produkte/2000 